\title{
Embryonic and larval development of Gobius paganellus (Pisces: Gobiidae)
}

\author{
Rita Borges*, Cláudia Faria**, Fátima Gil ${ }^{\dagger}$, Emanuel J. Gonçalves* and Vitor C. Almada* \\ *Unidade de Investigação em Eco-Etologia, Instituto Superior de Psicologia Aplicada, R. Jardim do Tabaco 34, \\ P-1149-041 Lisboa, Portugal. ${ }^{\dagger}$ Aquário Vasco da Gama, R. Direita, Dafundo, P-1495 Lisboa, Portugal. \\ ${ }^{\ddagger}$ Corresponding author, e-mail: cfaria@ispa.pt
}

The full developmental sequence from egg to juvenile of Gobius paganellus under controlled conditions is

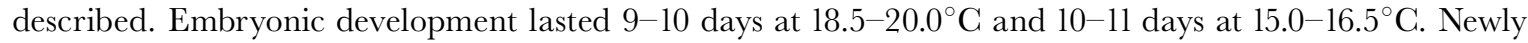
hatched larvae measured $3.90 \mathrm{~mm}$, had the mouth and anus opened, pigmented eyes and almost no yolk. They first settled 25 days after hatching (10.0-10.5 mm total length [TL]) and showed juvenile behaviour and body form 36 days after hatching $(14.0 \mathrm{~mm}$ TL). However, they only showed full juvenile pigmentation patterns 15 days later $(17.0 \mathrm{~mm} \mathrm{TL})\left(16.0-16.5^{\circ} \mathrm{C}\right)$. In addition, a preliminary differentiation between the newly hatched larvae of the most common Gobius species of south-western European shores is presented.

\section{INTRODUCTION}

The family Gobiidae is the largest of marine fish, being a very important element of temperate and tropical reef fish communities (Nelson, 1994). The ecology and biology of many species is well studied (Miller, 1984) but the early ontogenetic development of the Atlantico-Mediterranean species is poorly known with very few descriptions of eggs and larvae (Ruple, 1984).

Gobius paganellus (Linnaeus, 1758) is one of the most abundant gobies found along Portuguese rocky shores (Henriques et al., 1999). The distribution of this species ranges from western Scotland to tropical West Africa (Senegal), including the oceanic Islands, Mediterranean and Black Sea, Gulf of Eilat and Red Sea (Miller, 1986). Although the biology of this species has been considerably studied (e.g. Lebour, 1919a; Miller, 1961; Faria \& Almada, 1995) the information available about its development is scattered and incomplete (see Russell, 1976). Nests and eggs have been described by Holt \& Byrne (1898), Lo Bianco (1909), Hefford (1910), Lebour (1919a), Spartà (1934), Miller (1961), Faria \& Almada (1995).

In this paper the full developmental sequence of G. paganellus from egg to juvenile is described for laboratory reared fish. The identification of fish early developmental stages being one of the main problems in icthyoplankton studies, we have also systematized the available information on the newly hatched larvae of Gobius species and other genus commonly found in south-western European shores.

\section{MATERIALS AND METHODS}

Eggs and larvae were obtained from a captive pair of fish (female: $10.6 \mathrm{~cm}$ total length [TL]; male: $9.4 \mathrm{~cm}$ TL) maintained since January 2000 at a public aquarium (Aquário Vasco da Gama, Lisbon). Fish were fed daily with fish and shrimp. The 110-l tank was illuminated with natural light. The bottom of the tank was covered with a sand layer and some large flat stones were provided as shelter and breeding sites.

Five batches were obtained, but the complete sequence of embryonic development described is based only on two of those: 28 February 2000 (mean temperature $=19.1^{\circ} \mathrm{C}$;

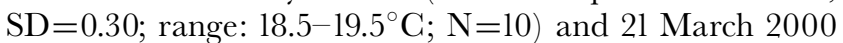
(mean temperature $=15.6^{\circ} \mathrm{C}$; $\mathrm{SD}=0.45$; range: $15.0-16.0^{\circ} \mathrm{C}$; $\mathrm{N}=11$ ). The eggs of a third batch (18 February 2000: mean temperature $=19.0^{\circ} \mathrm{C}$; $\mathrm{SD}=0.55$; range: $18.5-20.0^{\circ} \mathrm{C}$; $\mathrm{N}=11$ ) were also measured. Eggs were removed daily from the stone guarded by the male by aspiration with a tube.

Full larval development is described from three batches that hatched at: 18 February 2000 (mean temperature $=20.1^{\circ} \mathrm{C} ; \mathrm{SD}=0.80$; range: $\left.18.5-21.5^{\circ} \mathrm{C} ; \mathrm{N}=42\right), 8$ March 2000 (mean temperature $=19.0^{\circ} \mathrm{C}$; $\mathrm{SD}=1.38$; range: $17.0-21.5^{\circ} \mathrm{C} ; \mathrm{N}=66$ ) and 20 April 2000 (mean temperature $=16.3^{\circ} \mathrm{C} ; \mathrm{SD}=0.34$; range: $\left.16.0-17.0^{\circ} \mathrm{C} ; \mathrm{N}=96\right)$.

Upon hatching larvae were collected by aspiration and were reared in glass 30-1 tanks illuminated with fluorescent light (18 W) $24 \mathrm{~h}$ per day. A constant flow of seawater was maintained. Larvae were fed three times a day with Brachionus sp. enriched with Selco (Artemia Systems) and algae, which were mixed with Artemia sp. nauplii 28 days after hatching and replaced by Artemia sp. nauplii by day 41 .

Larvae were collected daily until metamorphosis. Eggs and anaesthetized larvae (Hypnodil, Janssen Pharmaceutica) were measured and observed under a Nikon stereomicroscope, photographed with a Nikon FX-35DX camera and preserved in 5\% buffered formalin. After preservation the egg capsules were opened and the embryos distended to allow more detailed observations. All larval measurements correspond to total lengths.

\section{RESULTS}

Breeding started soon after the male and female were placed together. We recorded and followed five spawnings that occurred at successively longer intervals (Table 1). The 
Table 1. Time of embryonic development at different temperatures and spawning intervals between batches.

\begin{tabular}{llclc}
\hline Batch & & Developmental time (days) & Spawning intervals (days) & Temperature range $\left({ }^{\circ} \mathrm{C}\right)$ \\
\hline 1 & $18 / 2 / 2000$ & 10 & - & $18.5-20.0$ \\
2 & $28 / 2 / 2000$ & 9 & 0 & $18.5-19.5$ \\
3 & $10 / 3 / 2000$ & 9 & 2 & $18.5-19.5$ \\
4 & $21 / 3 / 2000$ & 10 & 2 & $15.0-16.0$ \\
5 & $10 / 4 / 2000$ & 11 & 9 & $16.0-16.5$ \\
\hline
\end{tabular}

female never laid eggs until the previous batch had hatched and in nature we found males of this species guarding eggs in different stages of development (Faria \& Almada, 1995). These facts provide additional evidence that the males of this species guard eggs of different females simultaneously (see also Le Danois, 1913; Vivien, 1939; Miller, 1961; Gibson, 1970).

The fusiform and transparent eggs (Figure 1, Table 2) correspond to the descriptions made by several authors (for a review see Russell, 1976). They were suspended on the underneath of a horizontal rock by filaments and were distributed in a single layer. Egg measurements for three batches are presented in Table 2. Egg size decreased significantly with successive broods (analysis of variance: $F=6.437 ; \mathrm{df}=2 ; P<0.01$; Tukey honestly significant difference test: $P<0.05$ in every comparison).

The ontogenetic events of embryonic development at different temperatures are shown in Table 3. Hatching occurred at day $9 / 10$ after spawning at $18.5-19.5^{\circ} \mathrm{C}$ (three batches) and at day $10-11$ after spawning at $15.0-16.0^{\circ} \mathrm{C}$ (two batches) (Table 1).
The hatching event was observed in one batch. Almost all eggs hatched in less than a minute. Immediately after hatching, all larvae swam with spiral movements to the surface, with successive swimming impulses, where they seemed to gulp air, likely to fill the gas bladder. This behaviour was performed repeatedly. About one hour later, the larvae stabilized their position and dispersed in the water column.

Figure 2 presents larvae collected at different developmental stages. The ontogenetic events of larval development at different temperatures are shown in Table 4. The newly hatched larvae measured $3.90 \mathrm{~mm} \quad(\mathrm{SD}=0.09$; range: $3.78-3.99 \mathrm{~mm} ; \quad \mathrm{N}=30$, temperature $\left.=16.0-17.0^{\circ} \mathrm{C}\right)$. The anus and mouth were opened, with formed lips and differentiated jaws (Figure 2). The yolk was almost fully absorbed. The liver was developed, the eyes were fully pigmented, and the gas bladder was formed but not completely filled. The pectoral fins were differentiated and the sagittae and lapilli otoliths were visible. The opercula were opened with four branchial arches present. The dorsal membrane of the gas bladder was fully pigmented. Ventrally there were some dispersed melanophores under
A



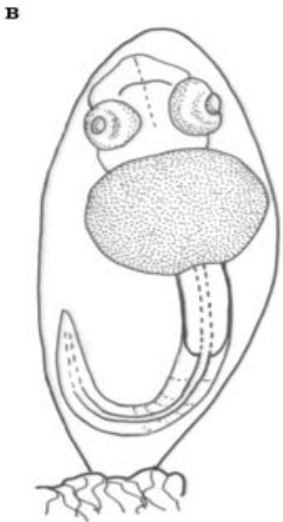

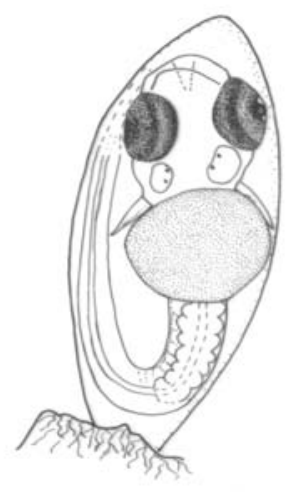

Figure 1. Eggs collected at different developmental stages: (A) embryo differentiation (day 1); (B) embryo as long as major axis (day 3$) ;(\mathrm{C})$ embryo prior to hatching (day 10).

Table 2. Egg height and width for three batches (data from eggs preserved in 5\% buffered formalin).

\begin{tabular}{|c|c|c|c|c|c|c|}
\hline Batch & & Average (mm) & $\mathrm{SD}$ & Range (mm) & $\mathrm{N}$ & Temperature range $\left({ }^{\circ} \mathrm{C}\right)$ \\
\hline \multirow[t]{2}{*}{1} & Height & 1.99 & 0.18 & $1.60-2.20$ & 14 & $18.5-20$ \\
\hline & Width & 0.86 & 0.07 & $0.80-0.90$ & 14 & \\
\hline \multirow[t]{2}{*}{2} & Height & 1.83 & 0.17 & $1.60-2.10$ & 31 & $18.5-19.5$ \\
\hline & Width & 0.80 & 0.09 & $0.70-0.90$ & 31 & \\
\hline \multirow[t]{2}{*}{4} & Height & 1.81 & 0.17 & $1.60-2.10$ & 40 & $15.0-16.0$ \\
\hline & Width & 0.80 & 0.14 & $0.70-0.90$ & 40 & \\
\hline
\end{tabular}




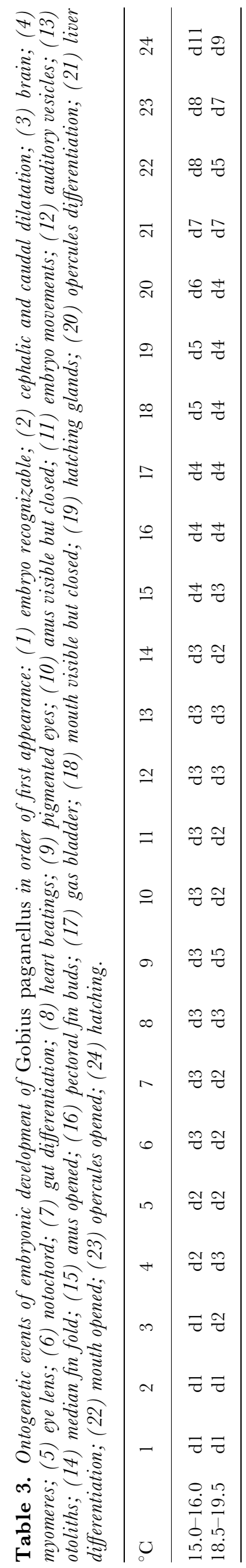

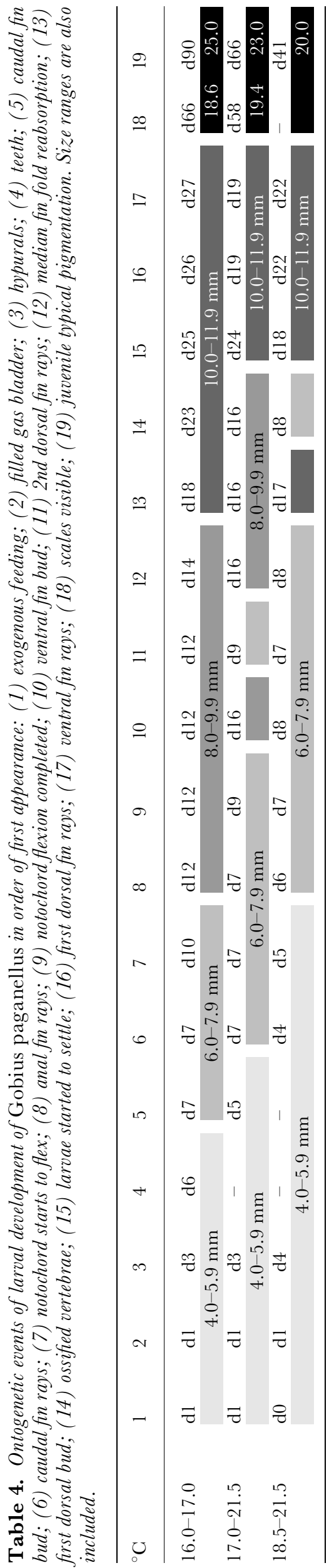




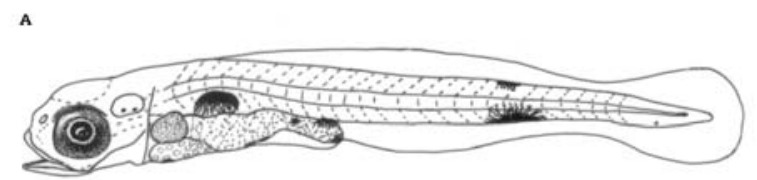

B

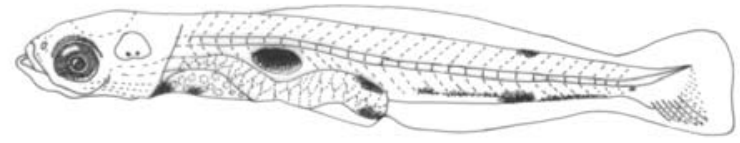

c
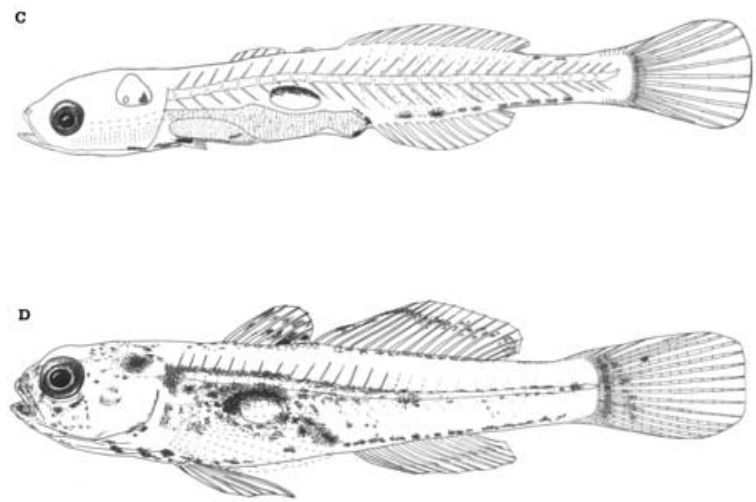

Figure 2. Larvae collected at different developmental stages: (A) newly hatched larva (day 0, $3.9 \mathrm{~mm}$ ); (B) caudal fin rays (day 9, $6.2 \mathrm{~mm}$ ); (C) all fin rays formed (day 28, $11.4 \mathrm{~mm}$ ); (D) juvenile (day 94, 22.2 mm).

the liver, the gut, and the anus, a large one over the anus and a series of ventral post-anal melanophores, with the middle one strongly ramified and a punctate pigment near the caudal tip. Dorsally, over the larger ventral pigment there was a ramified melanophore.

The pigmentation pattern changed with larval development. At day 13 after hatching $(7.5-8.0 \mathrm{~mm})$, when the larvae had already all the anal and 2nd dorsal fin rays $(\mathrm{A}=\mathrm{I}+11-12 \quad[10-13] ; \mathrm{D} 2=\mathrm{I}+13-14 \quad[12-15])$, a small melanophore was visible in the otic vesicle. Throughout development there was an increase in the number and intensity of pigment cells in this area. Ventrally, the large ramified melanophore disappeared and the number of melanophores increased until a row was visible from the throat to near the caudal peduncle. At day 25 (10.0$10.5 \mathrm{~mm})$, two rows of melanophores were visible at the insertion of the anal fin. By this time, there were melanophores on the base of the ventral rays of the caudal fin that tended to spread to the base of all the caudal fin rays. Around day $30(11.0-11.5 \mathrm{~mm})$ a melanophore appeared over the tip of the upper jaw and the ramification of the dorsal post-anal melanophore was reduced. At day $48(13.5-14.0 \mathrm{~mm})$ there were melanophores over the cephalic region that increased in size and number with development. Between day 25 and day 40 $(10.0-13.0 \mathrm{~mm})$ all other fin rays were present $(\mathrm{Dl}=$ $\mathrm{VI} ; \mathrm{P}=21-22$ [18-23]) By day $50(14.5-15.0 \mathrm{~mm})$ there was a row of melanophores extending over the vertebral column. Dorsal and pectoral fin pigmentation started at day 52 after hatching $\left(15.5^{-}-16.0 \mathrm{~mm}\right)$.
Larvae started to settle at day 25 after hatching at a size of 10.0-10.5 mm. The change to a benthic mode of life was gradual. Initially, they only touched the substratum returning immediately to the water column. Gradually, they began to stay longer at the bottom until definitely standing there.

At metamorphosis the fish became heavily pigmented. The general pattern of pigmentation was maintained but the anterior part of the body became strongly pigmented. There were two horizontal stripes of melanophores in the first dorsal fin and a horizontal stripe in the second dorsal fin and in the anal fin (less marked in this one). There was also an increase of pigmentation on the flanks and at the border of the scales in the posterior region of the body. Metamorphosis was a gradual process. In most fish a marked change of body form to that of a juvenile became apparent at day 36 after hatching, when they were about $14.0 \mathrm{~mm}$ (at $16.0-16.5^{\circ} \mathrm{C}$ ). At this time they began to show typical behaviours of a benthic fish, like jumping and hiding in the substrate. However, the acquisition of juvenile pigmentation only appeared at day 51 at a size of $17.0 \mathrm{~mm}$ TL. This agrees with observations made in the field, where the smallest fish collected in tidepools were about $17.0 \mathrm{~mm}$ (mean $=16.8 \mathrm{~mm} ; \mathrm{SD}=0.17$; range: $13.0-19.0 \mathrm{~mm} ; \mathrm{N}=64$ ), with some fish still lacking the juvenile general body shape and pigmentation (C.F., personal observations). At day 89 after hatching fish measured $2.5-3.0 \mathrm{~cm}$.

\section{DISCUSSION}

Egg structure agreed with the descriptions available (Lebour, 1919a; Spartà, 1934; Padoa, 1956; Miller, 1961; Russell, 1976) but egg size was smaller than data presented by several authors: $2.0-3.0 \mathrm{~mm}$ height and $0.74-1.0 \mathrm{~mm}$ wide (see Spartà, 1934; Miller, 1961; Russell, 1976). However, they are similar to those presented by Holt \& Byrne (1898) who described eggs laid in an aquarium (1.84-1.9 mm), and with data from eggs measured in the field, in Portugal (Faria \& Almada, 1995). These data should be analysed with care because we observed not only some variability in egg size from the same batch, but also a reduction in egg size with the number of broods of the same female which could be related to metabolic exhaustion of the female, an observation also made by Potts \& Wootton (1984). As temperature changed between the second and third batch analysed, it could be argued that it was the drop in temperature and not female exhaustion that caused the decrease in egg size. Although the available data are insufficient to assess these two hypotheses, the finding that between the first and second batch produced at similar temperatures there was already a significant decrease in egg size, provides a preliminary indication that female exhaustion may be a more important factor than temperature in the reduction of egg size. Further work is however needed to resolve this issue.

The basic sequence of embryonic developmental events was maintained at different temperatures. However there was some delay in the timing of appearance of some structures at a lower temperature, a long known phenomenon in fish development (Blaxter, 1969). In another common gobiid species, Gobius cobitis, where the embryonic development was studied at two temperature ranges: $12.0-16.0^{\circ} \mathrm{C}$ (Gil et al., 1997) and 15.0-18.0 ${ }^{\circ} \mathrm{C}$ (our unpublished results) 
this was also observed. However, in our study the delay in the timing of appearance of some structures at a lower temperature was more evident. This could be related to the minimum temperature of the first batch $\left(16.0-17.0^{\circ} \mathrm{C}\right)$ that was lower than the subsequent batches $\left(17.0-21.0^{\circ} \mathrm{C}\right)$.

In the present study larvae hatched at $3.90 \mathrm{~mm}$, a size that is slightly smaller than the published values for this species, 4.00-4.80 mm (Hefford, 1910; Lebour, 1919; Spartà, 1934; Padoa, 1956). However, no information on temperature is provided for the previous studies, thus the extent to which this discrepancy is due to temperature differences, population characteristics or is simply a consequence of a large variability present in this species remains an open issue.

The basic sequence of larval development was similar at different temperatures, being faster at higher temperatures (see Table 4), with some differences: when the minimum temperature was higher the differentiation of the second dorsal fin rays and the ossified vertebrae was faster. The larval sequence obtained for this species agreed largely with the one presented by Gil et al. (1997) for G. cobitis. The main larval structures were all present between day 19 and day 27, and the larvae attained a similar size at the completion of development regardless of temperature. From this time to metamorphosis, the main emphasis seemed to be in growth and in the acquisition of juvenile characters (pigmentation patterns and body form), these changes being faster at higher temperatures (larvae took 49 days to grow $8.9 \mathrm{~mm}$ at $16.0^{\circ} \mathrm{C}-17.0^{\circ} \mathrm{G}$ and only 19 days at $18.5^{\circ} \mathrm{C}-21.5^{\circ} \mathrm{C}$ ).

At the current stage of knowledge about the development of north-eastern Atlantic gobiids, we believe that it is worthwhile to attempt a summary of characteristics that may help in the identification of eggs and larvae of the most common gobiids of this area. The eggs of gobies are demersal and laid in a single layer (Russell, 1976). For most species they are pear shaped (see Russell, 1976), but those of the common species of the genus Gobius, Gobius niger (Ballard, 1969; Iglesias, 1979), Gobius paganellus, Gobius cobitis (Gil et al., 1997) and Gobius cruentatus (Gil et al., 2002), are elongated and fusiform.

Within the genus Gobius, besides differences in egg size (height/width: 3.44-3.74/1.11-1.26 mm for G. cobitis (Gil et al., 1997); 1.90-2.10/0.50-0.60 mm for G. cruentatus (Gil et al., 2002); 1.60-2.20/0.70-0.90 for G. paganellus (our results); $1.50 \mathrm{~mm}$ height for $G$. niger (Iglesias, 1979)), the eggs of $G$. cobitis and $G$. cruentatus show the apex less rounded than $G$. niger and $G$. paganellus. Between these two pairs of species, egg size is sufficiently different to allow species identification. Also, the habitat of $G$. niger (sand) is very different from that of $G$. paganellus (rock) (Miller, 1986).

The newly hatched larvae of Gobiidae show a typical shape, slender and elongate, with a prominent gas bladder. The basic pattern of pigmentation consists of a ventral post-anal row of melanophores, often with a larger one at about half the distance between the anus and the urostyle, and strong pigmentation in the dorsal part of the gas bladder (Petersen, 1919; Lebour, 1919a,b; Gil et al., 1997, 2002; see Russell, 1976 for a review). Most larvae hatch with functional mouth and anus that allow exogenous feeding, and pigmented eyes and developed pectoral fins that allow active swimming immediately after hatching (Gil et al., 1997, 2002; see Russell, 1976 for a review).
In spite of these similarities, there are some differences that can distinguish early larvae of Gobius from other gobiid genera present in our study area, and between the four Gobius species discussed here, based mainly on the pigmentation patterns and body shape.

Newly hatched larvae of Lebetus can be distinguished from other Gobiidae by a heavily pigmented body (except on the caudal region) with a well marked median lateral row of melanophores (see Petersen, 1919; Demir \& Russell, 1971; Russell, 1976; Ré, 1980/1981). Crystallogobius with less than $6.0 \mathrm{~mm}$ can be distinguished by a strong pigmentation on the head (in front of the eyes, on the lower jaw and in the otic vesicle) and by five large melanophores between the head and tail (see Lebour, 1919a; Petersen, 1919; Russell, 1976). Newly hatched larvae of Gobiusculus flavescens and Pomatoschistus spp. described in the literature, present a pigment in the angle of the lower jaw which is never present in the described Gobius larvae (see Petersen, 1919; Lebour, 1919a,b, 1920; Padoa, 1956; Russell, 1976).

Distinction between Gobius and other genera in the subsequent stages of development is possible by counting fin rays and vertebrae and by analysing pigmentation patterns (see Petersen, 1919; Lebour, 1919a,b, 1920; Russell, 1976).

Within the genus Gobius, newly hatched larvae can be distinguished mainly by their pigmentation patterns and size at hatching: both $G$. cobitis and $G$. cruentatus have a melanophore ventro-posterior to the otic vesicle that is not present in G. niger or G. paganellus larvae (however, in these species otolith pigmentation appears later in development).

Larvae of $G$. cobitis hatch with a size of $5.08-5.5 \mathrm{~mm}$, and already present several dorsal pre-anal melanophores (which are maintained as larvae develop-see Gil et al., 1997), while newly hatched $G$. cruentatus larvae, hatch with a size of $3.3 \mathrm{~mm}$ (Gil et al., 2002), and have no dorsal preanal melanophores (larval development of this species is not known).

According to our results for G. paganellus and the descriptions available in the literature for $G$. niger newly hatched larva (see Petersen, 1919; Lebour, 1919a; Ballard, 1969; Iglesias, 1979), it is not possible to distinguish these two species based on pigmentation patterns. Gobius niger larvae are smaller at hatching $(2.5-3.0 \mathrm{~mm})$ when compared with G. paganellus $(3.9 \mathrm{~mm})$ and present a faster development: settlement occurs when larvae measure about $9.0 \mathrm{~mm}$ (vs $10.0-10.5 \mathrm{~mm}$ in G. paganellus) and at this time almost all adult characters are present, while in G. paganellus metamorphosis only occurs at about $17.0 \mathrm{~mm}$.

For the other species of the genus Gobius present in our study area, Gobius bucchichi, Gobius gasteveni, Gobius roulei and Gobius xantocephalus there is no information on larval development (Miller, 1986). Although information on egg and larval development is not available for some Gobius species present in our study area, the four species discussed here are the most common (Henriques et al., 1999). Therefore, the comparison presented may help to perform a preliminary screening of Gobius larvae when inspecting icthyoplankton samples for this biogeographic region. It should, however, be taken into consideration that laboratory reared larvae may present some important differences to those collected in the field (Leis, 1987).

This study was supported by Fundação para a Ciência e Tecnologia (FCT) as part of the project PRAXIS XXI/3/3.2/ 
EMG/1957/95 and the Pluriannual Program (UI\&D 331/94). C.F. was also supported by a grant from FCT (PRAXIS XXI/ $\mathrm{BD} / 5666 / 95)$. We would like to thank the technicians of Vasco da Gama Aquarium for the help in the maintenance of tanks, Rita Lourenço for the illustrations and two anonymous referees for valuable comments on the manuscript.

\section{REFERENCES}

Ballard, W.W., 1969. Normal embryonic stages of Gobius niger jozo. Pubblicazioni della Stazioni Zoologica di Napoli, 37, 1-17.

Blaxter, J.H.S., 1969. Development: eggs and larvae. Fish Physiology, III, 178-252.

Demir, N. \& Russell, F.S., 1971. On the postlarva of the goby Lebetus. Fournal of the Marine Biological Association of the United Kingdom, 51, 669-678.

Faria, C. \& Almada, V.C., 1995. Some aspects of the breeding ecology of Gobius cobitis Pallas and Gobius paganellus L. in the west coast of Portugal. Arquivos do Museu Bocage-Nova Série, II, 463-471.

Gibson, R.N., 1970. Observations on the biology of the giant goby Gobius cobitis Pallas. Fournal of Fish Biology, 2, 281-288.

Gil, M., Borges, R., Faria, G. \& Gonçalves, E.J., 2002. Early development of the red mouthed goby, Gobius cruentatus (Pisces: Gobiidae). Fournal of the Marine Biological Association of the United Kingdom, 82, 161-163.

Gil, M.F., Gonçalves, E.J., Faria, C., Almada, V.C., Baptista, C. \& Carreiro, H., 1997. Embryonic and larval development of the giant goby Gobius cobitis (Pisces: Gobiidae). Fournal of Natural History, 31, 799-804.

Hefford, A.E., 1910. Notes on teleostean ova and larvae observed at Plymouth in spring and summer, 1909. Fournal of the Marine Biological Association of the United Kingdom, 9, 2-58.

Henriques, M., Gonçalves, E.J. \& Almada, V.C., 1999. The conservation of littoral fish communities: a case study at Arrábida coast (Portugal). In Behaviour and conservation of littoral fishes (ed. V.C. Almada et al.), pp. 473-519. Lisboa: ISPA.

Holt, E.W.L. \& Byrne, L.W., 1898. Notes on the reproduction of teleostean fishes in the south-western district. Fournal of the Marine Biological Association of the United Kingdom, 5, 333-340.

Iglesias, J., 1979. Eficiencias de crescimiento y fases embrionarias de Gobius niger, L. 1758 (Gobiidae, Pisces) sujeto a condiciones experimentales. Boletin del Instituto Español de Oceanografia, 277, 163-172.

Lebour, M.V., 1919a. The young of the Gobiidae from the neighbourhood of Plymouth. Fournal of the Marine Biological Association of the United Kingdom, 12, 48-80.
Lebour, M.V., 1919b. Further notes on the young Gobiidae from the neighbourhood of Plymouth. Fournal of the Marine Biological Association of the United Kingdom, 12, 146-148.

Lebour, M.L., 1920. The eggs of Gobius minutus, pictus and microps. Fournal of the Marine Biological Association of the United Kingdom, 12, 253-260.

Le Danois, E., 1913. Contribution à l'étude systématique et biologique des poissons de la Manche Occidentale. Annales de l'Institut Océanographique, Monaco, 5, fasc. 5.

Leis, J.M., 1987. Minimum requirements for published descriptions of larval fish development. Australian Ichthyoplankton Newesletter, 2, 4-5.

Lo Bianco, S., 1909. Notizie biologische riguardanti specialmente il periodo di maturità sessuale degli animali del golfo di Napoli. Mitteilungen der Zoologischen Station in Neapel, 19, 513-761.

Miller, P.J., 1961. Age, growth and reproduction of the rock goby, Gobius paganellus L., in the Isle of Man. Fournal of the Marine Biological Association of the United Kingdom, 41, 737-769.

Miller, P.J., 1984. The tokology of gobioid fishes. In Fish reproduction: strategies and tactics (ed. G.W. Potts and R.J. Wootton), pp. 119-153. London: Academic Press.

Miller, P.J., 1986. Gobiidae. In Fishes of the north-eastern Atlantic and the Mediterranean (ed. P.J.P. Whitehead et al.), pp. 1019-1085. Paris: UNESCO.

Nelson, J.S., 1994. Fishes of the world, 3rd edn. New York: John Wiley \& Sons.

Padoa, E., 1956. Gobiidae. Fauna e flora del Golfo di Napoli, Monogr. 38 ( $3^{\text {a }}$ Puntata), I Parte, 648-678.

Petersen, C.G.J., 1919. Our gobies (Gobiidae). From the egg to the adult stages. Report of the Danish Biological Station, 26, 45-66.

Potts, G.W. \& Wootton, R.J., 1984. Fish reproduction: strategies and tactics. London: Academic Press.

Ré, P., 1980/1981. On the occurrence of postlarval stages of Lebetus (Pisces: Gobiidae) off Portugal. Boletim da Sociedade Portuguesa de Ciências Naturais, 20, 67-69.

Ruple, D., 1984. Gobioidei: development. In Ontogeny and systematics of fishes (ed. H.G. Moser et al.), pp. 582-587. Lawrence: The American Society of Ichtyologists and Herpetologists.

Russell, F.S., 1976. The eggs and planktonic stages of British marine fishes. London: Academic Press.

Spartà, A., 1934. Uova e larve di Gobiidae. I.—Gobius paganelus L. Regio Comitato Talassografico Italiano, 211, 1-10.

Vivien, J.H., 1939. Étude préliminaire des annexes du tractus genital d'un Gobiidé: Gobius paganellus L. Travaux de la Station Zoologique de Wimereux, 13, 713-721.

Submitted 10 February 2002. Accepted 13 May 2003. 